\title{
IMPACTS OF GRAZING INTENSITY ON NITROGEN POOLS AND NITROGEN CYCLE IN AN ALPINE MEADOW ON THE EASTERN TIBETAN PLATEAU
}

\author{
Y.H. GAO ${ }^{1}-$ P. $\mathrm{LUO}^{2}-$ N. WU ${ }^{2} *-$ H. $\mathrm{CHEN}^{2}-$ G.X. WANG \\ ${ }^{1}$ Institute of Mountain Hazards and Environment, Chinese Academy of Sciences and Ministry of \\ Water Resources, P. O. Box 417, Chengdu 610041, Sichuan Province, China \\ (phone: 0086-28-85228816; fax: 0086-28-85222258) \\ ${ }^{2}$ Chengdu Institute of Biology, Chinese Academy of Sciences, P. O. Box 416, Chengdu 610041, \\ Sichuan Province, China \\ (phone: 0086-28-85220920; fax: 0086-28-85222753) \\ *Corresponding author \\ e-mail:yhgao@imde.ac.cn
}

(Received $21^{\text {th }}$ August 2007; accepted $3^{\text {rd }}$ March 2008)

\begin{abstract}
Grazers may influence nitrogen $(\mathrm{N})$ pools and alter $\mathrm{N}$ inputs and outputs (losses) to the ecosystem in a number of ways. In this study, we evaluated $\mathrm{N}$ pools within the plant-soil system (0-30 $\mathrm{cm}$ ) and soil $\mathrm{N}$ transformation under three different grazing intensities by yaks (light: 1.2, moderate: 2.0, and heavy: 2.9 yaks ha $^{-1}$ ) in an alpine meadow on the eastern Tibetan Plateau. Total plant and soil $\mathrm{N}$ at 0 $30 \mathrm{~cm}$ depth tended to increase as grazing intensity increasing (plant $\mathrm{N}: 26.6,31.4$ and $36.7 \mathrm{~g} \mathrm{~m}^{-2}$; soil N: 905,939 and $1125 \mathrm{~g} \mathrm{~m}^{-2}$ for light, moderate and heavy grazing, respectively). Soil $\mathrm{N}$ transformation rates, such as net $\mathrm{N}$ mineralization, gross nitrification, denitrification and $\mathrm{N}_{2} \mathrm{O}$ emissions, generally increased under heavy grazing intensity. Results indicate that heavy grazing intensity accelerated the $\mathrm{N}$ cycling rates between system components and leaded to increases in plant-soil system $\mathrm{N}$ in this alpine meadow.

Keywords: biomass; grassland; $N$ stocks; soil $N$ transformation; Tibet Plateau
\end{abstract}

\section{Introduction}

Grasslands occupy approximately one-third of the earth's terrestrial surface and are subject to varying degrees of management by humans $[1,2]$. Grazing by livestock is a widely used management tool in grasslands, impacts ecosystem structure and plays a role in regulating nutrient cycling and energy flow [3]. $\mathrm{N}$ limits primary production in many terrestrial ecosystems [4]. Determining the role that herbivores play in regulating $\mathrm{N}$ storage and cycling in grassland ecosystems is important to understanding not only the grasslands themselves, but also the contribution of grasslands to global nitrogen fluxes.

Grazers can return large amounts of $\mathrm{N}$ to the soil through urine and feces, increasing levels of available soil $\mathrm{N}[3,5,6,7,8]$. Herbivores also increase decomposition rates by reducing $\mathrm{C} / \mathrm{N}$ ratios of plants $[3,9,10]$. Furthermore, plants often respond to defoliation by decreasing root production $[10,11,12]$ that can result in reduced soil $\mathrm{C}$ and $\mathrm{C} / \mathrm{N}$ ratios [10]. Lower $\mathrm{C} / \mathrm{N}$ ratios in grazed plant material and soils increases net $\mathrm{N}$ mineralization by reducing microbial demand for $\mathrm{N}$ (i.e., microbial immobilization) during decomposition [10, 13]. However, grazing can also reduce $\mathrm{N}$ turnover and availability, as grazers feed selectively on plants with high $\mathrm{N}$ content and thus increase the dominance of plant species with low $\mathrm{N}$ content, and litter from those species decomposes slowly. Moreover, reducing $\mathrm{N}$ availability favors $\mathrm{N}$-poor species because 
they are often better nitrogen competitors $[14,15,16]$. In this case, grazers reduce aboveground productivity and the rate of $\mathrm{N}$ cycling. Thus, grazers may have different or even opposite effects on $\mathrm{N}$ cycling in different systems and may consequently shift ecosystem productivity in either a positive or negative direction.

The Tibetan Plateau, the largest geo-morphological unit on the Eurasian continent, is an important part of the global terrestrial ecosystem, and one of the major pasture lands in China. Alpine meadows, covering about $35 \%$ of the plateau area, are a representative vegetation type and the major grazing land of the region, especially in eastern areas [17]. Long-term overgrazing in the areas has resulted in considerable deterioration and even desertification [18]. However, few data exist quantifying the magnitude and distribution of $\mathrm{N}$ stored, and the effects of grazing management on the biogeochemical processes controlling the exchanges of $\mathrm{N}$ between the soil and atmosphere.

This study was conducted to examine impacts of three grazing intensities on $\mathrm{N}$ pools and soil $\mathrm{N}$ cycling in alpine meadow on the eastern Tibetan Plateau. Objectives were to quantify and compare the effects of grazing intensity on (1) plant species composition; (2) above- and belowground biomass; (3) N storage in plants and soil; and (4) soil N transformations, including net $\mathrm{N}$ mineralization, net nitrification, gross nitrification, denitrification and $\mathrm{N}_{2} \mathrm{O}$ emissions.

\section{Materials and methods}

\section{Study site}

The study site is approximately 140 ha and located at Hongyuan County, Sichuan Province, China $\left(33^{\circ} 03^{\prime} \mathrm{N}, 102^{\circ} 36^{\prime} \mathrm{E}\right)$ and has been previously used as traditional winter pasture (early November to mid-May) by local Tibetan nomads with light grazing intensities [19]. It is $3462 \mathrm{~m}$ above sea level, with a continental harsh climate. Annual precipitation averages $752 \mathrm{~mm}$, with about $86 \%$ received from May through September. Mean annual temperature is $1.1^{\circ} \mathrm{C}$ and there is not an absolute frost-free period. The highest monthly mean temperature is $10.9^{\circ} \mathrm{C}$ in July and the lowest is $-10.3^{\circ} \mathrm{C}$ in January. The dominant species in the whole area was Clinelymus nutans and Roegneria nutans, accompanied by Koeleria litwinowii, Agrostis schneideri, Kobresia setchwanensis and Anemone rivularis. The vegetation covered over 90\% [19]. Soils are Mat Cry-gelic Cambisols [20]. Soil organic matter and total N were 61.20 and 3.42 $\mathrm{g} \mathrm{kg}^{-1}$, respectively [21].

In 1997, the study site was segregated into several pastures and contracted out to different farmers who established fences to enclose their own pastures. This caused a shift and redistribution of livestock across the study site with grazing intensities varying by farmer, but consistent among years for a given pasture. Three adjacent experimental sites, each with a different grazing intensity, were chosen for study. All the sites had been used as winter pasture with a continuous grazing period from early November to the end of May. Light grazing intensity (LG) was 1.2 yaks $^{-1}{ }^{-1}$ which resulted in 20 to $35 \%$ utilization of annual forage production for the 16 ha pasture area, and vegetation was dominated by Roegneria nutans, Deschampsia caespitosa, and Elymus nutans. Moderate grazing intensity was 2.0 yaks ha $^{-1}$, resulting in 40-50\% utilization over the 28 ha pasture, with vegetation dominated by Kobresia setchwanensis, Kobresia pygmaea, and Roegneria nutans. Heavy grazing intensity was 2.9 yaks $^{-1}{ }^{-1}$, resulting in 60-75\% utilization over the 20 ha pasture, with vegetation dominated by Kobresia pygmaea, Kobresia setchwanensis, and Potentilla anserina. 


\section{Field sampling and investigation}

In August 2005, five $10 \mathrm{~m} \times 10 \mathrm{~m}$ plots were randomly selected in each experimental site. Each plot was located at least $12 \mathrm{~m}$ from the next nearest replicate. In each plot five $50 \times 50 \mathrm{~cm}$ quadrates were randomly selected for biomass sampling. Aboveground biomass was clipped to ground level as living biomass and dead biomass (standing dead and litter). Root biomass was measured by collecting 5 soil cores $(20 \mathrm{~cm}$ in diameter) from depths of $0-30 \mathrm{~cm}$ in each plot, which were co-located with the aboveground biomass measurement quadrates. The soil cores $(20 \mathrm{~cm}$ diameter $)$ were cut into segments corresponding to sampling depths of 0-10, 10-20, and 20-30 cm. These cores were immediately washed over a 1-mm mesh screen to remove soil.

Plant community characteristics were determined from two systematically located transects $(50 \mathrm{~cm} \times 500 \mathrm{~cm})$ of ten continuous quadrates $(50 \mathrm{~cm} \times 50 \mathrm{~cm})$ in each plot. Plant species were identified and recorded, the total ground cover, species canopy cover, and height determined from $0.25 \mathrm{~m}^{2}$ quadrates. The frequency of each plant species was calculated for each plot. Importance data for individual species were calculated as averages of their relative abundance in terms of canopy cover, height, and frequency.

Within each plot, composite soil samples consisting of 5 soil cores $7.5 \mathrm{~cm}$ in diameter of 30-cm depth were taken from the same five quadrates in which biomass was harvested and root cores were taken. All plant litter was removed from the soil surface before the sampling. Soil samples were segregated into 0-10, 10-20, 20-30 cm increments. Duplicate soil cores were also taken at each sampling quadrate for soil bulk density determination, which were used to convert soil $\mathrm{N}$ concentrations (in grams per kilogram) to $\mathrm{N}$ mass (in grams per square meter) in the soil.

Rates of in situ net $\mathrm{N}$ mineralization and nitrification were evaluated in the field using the buried-bag technique [22]. Five paired soil cores $(5 \mathrm{~cm}$ diameter, $5 \mathrm{~cm}$ depth) were taken from random locations in each plot. In each pair, one soil core was sealed in a gas permeable polyethylene bag and buried at a depth of $5 \mathrm{~cm}$. The other core (initial) was taken adjacent to each buried bag and kept in cooler bags during the transportation to the laboratory prior to freezing for analyses. The buried bags were retrieved after 30 days of incubation and analyzed for $\mathrm{NH}_{4}{ }^{+}-\mathrm{N}$ and $\mathrm{NO}_{3}{ }^{-}-\mathrm{N}$. Net $\mathrm{N}$ mineralization was calculated by subtracting initial $\mathrm{NH}_{4}{ }^{+}-\mathrm{N}$ plus $\mathrm{NO}_{3}{ }^{-}-\mathrm{N}$ concentrations from final concentrations. Net $\mathrm{N}$ nitrification was calculated as the difference in corresponding $\mathrm{NO}_{3}{ }^{-}-\mathrm{N}$ concentrations.

We measured gross rates of nitrification, denitrification and $\mathrm{N}_{2} \mathrm{O}$ emissions on intact cores using the Barometric Process Separation (BaPS) technique adapted for laboratory incubations [23]. Five intact soil cores $(5.6 \mathrm{~cm}$ diameter, $4 \mathrm{~cm}$ depth) from each plot were collected, which co-located with the other soil cores. The cores were cooled with freezer blocks and returned to the laboratory in insulated boxes for immediate analysis.

\section{Laboratory and statistical analyses}

Soil samples intended for $\mathrm{N}$ analyses were passed through a 2-mm screen to remove plant crowns, visible roots and root fragments. Samples were air-dried and analyzed for total $\mathrm{N}$ by the semi-micro Kjeldahl procedure [24]. Soil extracts were analyzed for $\mathrm{NH}_{4}{ }^{+}-\mathrm{N}$ with the potassium chloride-indophenol blue colorimetric method, and $\mathrm{NO}_{3}{ }^{-}-\mathrm{N}$ with calcium sulfate-phenol disulfonic acid method [24].

When soil $\mathrm{N}$ transformations were measured, five intact soil samples were directly filled into the BaPS instrument and the system was closed gas tight and incubated at a 
temperature of $11.7^{\circ} \mathrm{C}$ (average air temperature in August). Determination of soil $\mathrm{N}$ processes via the BaPS technique lasted approximately 12 hours [23].

All plant samples were oven-dried for $48 \mathrm{~h}$ at $65^{\circ} \mathrm{C}$ and weighed. Dry samples were then milled and analyzed for $\mathrm{N}$ content with the same method as soil sample.

Data were statistically analyzed by one-way analysis of variance (ANOVA) and significant differences were tested by the least significant difference (LSD) at $p<0.05$.

\section{Results}

\section{Plant species composition}

Difference in plant species composition was observed between the treatments (Table 1).

Table 1. Composition of species and their importance value at the three study sites

\begin{tabular}{|c|c|c|c|}
\hline Species name & Light grazing & Moderate grazing & Heavy grazing \\
\hline Roegneria nutans & 18.48 & 8.72 & 6.06 \\
\hline Elymus nutans & 8.54 & 4.20 & 3.75 \\
\hline Deschampsia caespitosa & 11.43 & 4.20 & \\
\hline Agrostis schneider & 4.18 & & \\
\hline Koeleria litwinowii & 4.67 & 5.68 & \\
\hline Kobresia setchwanensis & 7.68 & 17.43 & 23.32 \\
\hline Kobresia pygmaea & 1.70 & 5.25 & 12.54 \\
\hline Gueldenstaedtia diversifolia & 3.76 & 3.79 & 3.34 \\
\hline Oxytropis ochrocephala & 2.09 & 2.78 & 4.25 \\
\hline Astragalus polycladus & & 2.09 & \\
\hline Aster alpinus & 4.81 & 6.99 & 2.78 \\
\hline Saussurea hieracioides & & 4.60 & 2.28 \\
\hline Taraxacum maurocarpum & 2.20 & 1.60 & 1.36 \\
\hline Ligularia virgaurea & & 1.85 & \\
\hline Leontopodium longifolium & 2.60 & 2.82 & 6.09 \\
\hline Anemone rivularis & 7.33 & 4.90 & 3.41 \\
\hline Consolida ajacis & 2.32 & 1.86 & \\
\hline Anemone trullifolia & & 2.48 & 2.51 \\
\hline Thalictrum alpinum & 1.80 & 2.26 & 1.80 \\
\hline Ranunculus brotherusii & 1.53 & 1.74 & 3.24 \\
\hline Potentilla anserina & 1.41 & 2.13 & 8.35 \\
\hline Potentilla discolor & 1.66 & & \\
\hline Geranium phlzowianum & 4.19 & 2.04 & 1.86 \\
\hline Polygonum viviparum & 2.55 & 5.42 & 4.11 \\
\hline Stellera chamaejasme & 1.32 & 1.81 & 3.78 \\
\hline Plantago depressa & 1.45 & 1.15 & 2.27 \\
\hline Gentiana algida & 2.30 & 1.88 & 2.88 \\
\hline Total species number & 23 & 25 & 20 \\
\hline Total cover $(\%)$ & 89.7 & 92.6 & 73.6 \\
\hline
\end{tabular}


Dominant plant species in the LG site were Roegneria nutans (18.48\% as importance value), Deschampsia caespitosa (11.43\%), and Elymus nutans (8.54\%), and Kobresia setchwanensis (7.68\%). Major species in the MG site were Kobresia setchwanensis (17.43\%), Roegneria nutans (8.72\%), Aster alpinus (6.99\%), and Koeleria litwinowii (5.68\%). In the HG site, Kobresia pygmaea (12.54\%), Kobresia setchwanensis $(23.32 \%)$, Potentilla anserine $(8.35 \%)$, and Leontopodium franchetii $(6.09 \%)$ were most dominant species. Vegetation coverage was highest in the MG site, intermediate in the LG site, and lowest in the HG site.

\section{Above- and belowground biomass}

Live, dead and total aboveground biomass was lower in the HG site compared to the other two sites, which did not differ (Table 2).

Across all sites, more than $85 \%$ of the total belowground biomass $(0-30 \mathrm{~cm})$ was in the surface $0-10 \mathrm{~cm}$ soil depth (Table 2). Total root biomass was lower in the LG site compared to the MG and HG sites, which did not differ. Root/shoot ratio was higher in the HG site, with MG and LG sites similar.

Table 2. Plant biomass $\left(\mathrm{g} \mathrm{m}^{-2}\right)$ as affected by grazing intensity

\begin{tabular}{lccc}
\hline System components & Light grazing & Moderate grazing & Heavy grazing \\
\hline Above ground & & & \\
Live biomass & $359.2 \pm 53.4 \mathrm{a}$ & $412.3 \pm 65.7 \mathrm{a}$ & $281.0 \pm 39.0 \mathrm{~b}$ \\
Dead biomass & $162.2 \pm 16.7 \mathrm{a}$ & $177.2 \pm 30.1 \mathrm{a}$ & $111.1 \pm 20.1 \mathrm{~b}$ \\
Total above ground biomass & $521.4 \pm 60.4 \mathrm{a}$ & $589.4 \pm 91.4 \mathrm{a}$ & $392.1 \pm 53.6 \mathrm{~b}$ \\
Roots & & & \\
$0-10 \mathrm{~cm}$ & $1523.1 \pm 184.1 \mathrm{c}$ & $2147.0 \pm 335.8 \mathrm{~b}$ & $2686.9 \pm 449.6 \mathrm{a}$ \\
$10-20 \mathrm{~cm}$ & $196.7 \pm 52.4$ & $228.5 \pm 82.7$ & $152.6 \pm 41.2$ \\
$20-30 \mathrm{~cm}$ & $78.7 \pm 14.8$ & $107.0 \pm 24.3$ & $84.1 \pm 16.0$ \\
Total roots & $1798.5 \pm 179.5 \mathrm{~b}$ & $2482.6 \pm 356.2 \mathrm{a}$ & $2923.6 \pm 481.3 \mathrm{a}$ \\
Roots/shoot ratio & $3.46 \pm 0.23 \mathrm{~b}$ & $4.27 \pm 0.77 \mathrm{~b}$ & $7.51 \pm 1.33 \mathrm{a}$ \\
Total plant biomass & $2319.9 \pm 232.6 \mathrm{~b}$ & $3072.0 \pm 397.1 \mathrm{a}$ & $3315.6 \pm 504.7 \mathrm{a}$ \\
\hline
\end{tabular}

Within rows, means \pm S.D. Different letters represent statistically significant at $\mathrm{p}<0.05$. $\mathrm{n}=5$.

\section{Plant and soil $N$ stocks}

Total $\mathrm{N}$ storage in the aboveground live and dead biomass was higher in the MG site compared to the LG and HG sites, which did not differ (Table 3). Total root N storage $(0-30 \mathrm{~cm})$ was higher in the HG site compared to the LG and MG sites, which were similar. Total plant (aboveground + roots) $\mathrm{N}$ was greater in the $\mathrm{HG}$ site than in the MG and LG sites.

Soil $\mathrm{N}$ tended to decrease with increasing of soil depth (Table 3). Soil N storage (0$30 \mathrm{~cm})$ was higher in the HG site compared to the LG and MG sites, which did not differ.

Total $\mathrm{N}$ was higher in the HG site than the other two grazing intensities, which did not differ (Table 3). 
Table 3. Total amounts of $N$ stored in plant and soil pools $\left(\mathrm{g} \mathrm{m}^{-2}\right)$ as affected by grazing intensity

\begin{tabular}{lrcc}
\hline System components & Light grazing & Moderate grazing & Heavy grazing \\
\hline Above ground & & & \\
$\quad$ Live biomass & $4.4 \pm 0.6 \mathrm{~b}$ & $7.1 \pm 1.0 \mathrm{a}$ & $5.3 \pm 0.8 \mathrm{~b}$ \\
$\quad$ Dead biomass & $1.9 \pm 0.3 \mathrm{~b}$ & $2.8 \pm 0.6 \mathrm{a}$ & $1.6 \pm 0.2 \mathrm{~b}$ \\
$\quad$ Total above ground N & $6.3 \pm 0.8 \mathrm{~b}$ & $9.9 \pm 1.1 \mathrm{a}$ & $6.9 \pm 0.9 \mathrm{~b}$ \\
Roots & & & \\
$0-10 \mathrm{~cm}$ & $18.1 \pm 5.2 \mathrm{~b}$ & $19.3 \pm 4.6 \mathrm{~b}$ & $28.1 \pm 5.6 \mathrm{a}$ \\
$10-20 \mathrm{~cm}$ & $1.6 \pm 0.4$ & $1.6 \pm 0.7$ & $1.1 \pm 0.4$ \\
$20-30 \mathrm{~cm}$ & $0.6 \pm 0.1$ & $0.7 \pm 0.2$ & $0.6 \pm 0.1$ \\
Total roots N & $20.3 \pm 5.1 \mathrm{~b}$ & $21.6 \pm 5.0 \mathrm{~b}$ & $29.8 \pm 5.8 \mathrm{a}$ \\
Total plant N & $26.6 \pm 4.7 \mathrm{~b}$ & $31.4 \pm 5.0 \mathrm{ab}$ & $36.7 \pm 5.7 \mathrm{a}$ \\
Soil profile & & & \\
$0-10 \mathrm{~cm}$ & $395.8 \pm 43.8 \mathrm{~b}$ & $464.3 \pm 93.3 \mathrm{ab}$ & $541.8 \pm 63.2 \mathrm{a}$ \\
$10-20 \mathrm{~cm}$ & $289.0 \pm 36.1 \mathrm{~b}$ & $289.4 \pm 38.9 \mathrm{~b}$ & $359.5 \pm 58.6 \mathrm{a}$ \\
$20-30 \mathrm{~cm}$ & $219.9 \pm 31.0$ & $185.1 \pm 30.1$ & $223.7 \pm 27.2$ \\
Total soil N (0-30cm) & $904.7 \pm 77.0 \mathrm{~b}$ & $938.8 \pm 90.9 \mathrm{~b}$ & $1125.0 \pm 81.7 \mathrm{a}$ \\
Total ecosystem N (to 30cm) & $931.3 \pm 75.4 \mathrm{~b}$ & $970.2 \pm 89.2 \mathrm{~b}$ & $1161.7 \pm 84.3 \mathrm{a}$ \\
\hline
\end{tabular}

Within rows, means \pm S.D. Different letters represent statistically significant at $p<0.05$. $n=5$.

\section{Soil inorganic $N$}

Soil $\mathrm{NO}_{3}{ }^{-}-\mathrm{N}$ content in $0-5 \mathrm{~cm}$ depth was lower in the MG site than in the LG site or HG sites, which did not differ (Table 4). $\mathrm{NH}_{4}{ }^{+}-\mathrm{N}$ increased with increasing grazing intensity $(\mathrm{p}=0.006)$. Total inorganic $\mathrm{N}\left(\mathrm{NO}_{3}{ }^{-} \mathrm{N}+\mathrm{NH}_{4}{ }^{+}-\mathrm{N}\right)$ was higher in the HG site than in the LG and MG sites, which did not differ.

Table 4. Mass of soil inorganic $N\left(\mathrm{~g} \mathrm{~m}^{-2}\right)$ as affected by grazing intensity

\begin{tabular}{llll}
\hline & Light grazing & Moderate grazing & Heavy grazing \\
\hline $\mathrm{NO}_{3}{ }^{-} \mathrm{N}$ & $0.28 \pm 0.03 \mathrm{ab}$ & $0.23 \pm 0.02 \mathrm{c}$ & $0.32 \pm 0.05 \mathrm{a}$ \\
$\mathrm{NH}_{4}{ }^{-}-\mathrm{N}$ & $0.37 \pm 0.06 \mathrm{c}$ & $0.50 \pm 0.08 \mathrm{~b}$ & $0.64 \pm 0.13 \mathrm{a}$ \\
Total inorganic $\mathrm{N}$ & $0.65 \pm 0.09 \mathrm{~b}$ & $0.73 \pm 0.09 \mathrm{~b}$ & $0.96 \pm 0.18 \mathrm{a}$ \\
\hline
\end{tabular}

Within rows, means \pm S.D. Different letters represent statistically significant at $p<0.05$. $n=5$.

\section{Soil N transformations}

The HG site had higher net $\mathrm{N}$ mineralization, gross nitrification and denitrification rate than the LG site, with the MG site intermediate (Table 5). Net nitrification was higher at the $\mathrm{HG}$ compared to the $\mathrm{MG}$ site $(\mathrm{p}=0.080) . \mathrm{N}_{2} \mathrm{O}$ flux rate was higher in the HG site compared to the LG and MG sites, with no difference between the LG and MG sites. 
Table 5. Soil $N$ transformation rates $\left(m g \mathrm{Nm}^{-2} d^{-1}\right)$ as effected by grazing intensity

\begin{tabular}{lccc}
\hline & Light grazing & Moderate grazing & Heavy grazing \\
\hline Net N mineralization & $1.83 \pm 0.73 \mathrm{~b}$ & $2.54 \pm 0.97 \mathrm{ab}$ & $4.10 \pm 1.80 \mathrm{a}$ \\
Net N nitrification & $5.97 \pm 1.42 \mathrm{ab}$ & $3.42 \pm 0.99 \mathrm{~b}$ & $7.41 \pm 3.00 \mathrm{a}$ \\
Gross N nitrification & $226.4 \pm 57.9 \mathrm{~b}$ & $272.4 \pm 83.2 \mathrm{ab}$ & $344.3 \pm 30.2 \mathrm{a}$ \\
Denitrification & $23.79 \pm 4.56 \mathrm{~b}$ & $26.79 \pm 6.19 \mathrm{ab}$ & $36.56 \pm 10.16 \mathrm{a}$ \\
$\mathrm{N}_{2} \mathrm{O}$ emission rate & $2.98 \pm 0.50 \mathrm{~b}$ & $3.15 \pm 0.72 \mathrm{~b}$ & $4.62 \pm 1.47 \mathrm{a}$ \\
\hline
\end{tabular}

Within rows, means \pm S.D. Different letters represent statistically significant at $\mathrm{p}<0.05$. $\mathrm{n}=5$.

\section{Discussion}

The magnitude of impact that livestock grazing may have on a plant community is dependent upon intensity of grazing. In contrast to grazing at a light or moderate grazing intensity, grazing at heavy intensity has tended to decrease the numbers of grasses such as Roegneria nutans and Deschampsia caespitosa and increased the numbers of sedges such as Kobresia setchwanensis and K. pygmaea, which is good tolerant to be grazed, specially for yaks [25]. Heavy grazing also markedly reduced vegetation cover compared to light grazing and moderate grazing. This has an important implication for grassland management because vegetation cover is often used to assess spatial extent and degree of desertification [26].

Plant biomass is an important measure of ecosystem functioning for alpine meadows. After eight years grazing with different intensity, live, dead and total aboveground biomass was lower with heavy grazing compared to light or moderate grazing intensity. The reason for these results was that the dominator of HG community shifted from grasses-Roegneria nutans and Deschampsia caespitosa into sedges-Kobresia pygmaea and $K$. setchwanensis, which are small and good tolerant to be grazed [24]. Also, as our results demonstrated, a larger proportion of total production was allocated to the belowground biomass with heavy grazing [27]. Aboveground biomass decreased under heavy grazing intensity indicated that the winter forage supply for this region reduced and accordingly the pressure on native grassland productivity increased.

Root biomass responses to grazing are ambiguous. Milchunas and Lauenroth [28], Turner et al. [29], and Frank et al. [30] found mostly no changes, or increases, of root biomass as a function of grazing intensity. Our results suggested belowground biomass was lowest in the LG site and higher in both the MG and HG sites. This can be explained that heavy grazing induced more Kobresia pygmaea and K. setchwanensis, which have larger root system than that of Roegneria nutans and Deschampsia caespitosa [31]. This change was reflected in the higher root to shoot biomass ratio under the heavy grazing treatment compared to light grazing treatment. Biomass allocation ratio to root increasing is an adaptive response of plant to grazing. High proportion of root biomass in the total biomass can increase the capacity to tolerate environmental stresses and external disturbances, which is favorable for grassland restoration [32].

$\mathrm{N}$ storage of plants may depend on soil nitrogen availability [33, 34]. Our results supported the hypotheses because higher soil $\mathrm{N}$ availability occurred when grazing intensity increased. Moreover, greater availability of labile $\mathrm{N}$ in the soil on higher grazing intensity sites could increase plant uptake rate of $\mathrm{N}[30,35]$. In addition, a higher root biomass by increasing grazing intensity was contribution to plant $\mathrm{N}$ uptake 
[36]. Although high $\mathrm{N}$ storage in belowground biomass is common in grasslands [37], the effects of grazing intensity on this pattern were different (i.e., HG amplified this pattern compared to MG and LG). Those results suggested that grazing intensity changed the above- and belowground allocation of $\mathrm{N}$ within plant. Belowground $\mathrm{N}$ allocation may allow compensatory responses to grazers [29], and might also facilitate the recovery of vegetation after natural disturbance [38].

Soil N storage was higher under the heavy grazing intensity compared to the light grazing intensity, consistent with results for the northern mixed-grass prairie reported by Dormaar et al. [39] and Manley et al. [40]. The higher soil N under grazing intensity could be due to differences in root biomass between the treatments. Schuman et al. [41] and Hibbard et al. [42] reported larger root biomass can contribute more $\mathrm{C}$ and $\mathrm{N}$ to soil in northern mixed-grass and semi-arid grassland, respectively. In addition, the feces and urine from grazers are also important $\mathrm{N}$ source of soil [5, 8].

Heavy grazing had consistently higher soil $\mathrm{N}$ transformations than the light grazing in this alpine meadow ecosystem. These findings were more in line with corroborate those of Olofsson et al. [15] and Le Roux et al. [43] who all found that increasing grazing intensity increased soil $\mathrm{N}$ cycling rates. There were several mechanisms that could explain the increases of soil $\mathrm{N}$ processes under heavy grazing intensity. The $\mathrm{N}$ added by grazers in excrement is in forms available to plants and soil microbes $[3,5,6$, 7]. The increased litter decomposition resulted from grazer trampling. Faster decomposition means that less nitrogen was tied up in litter and nitrogen may cycle through the ecosystem more quickly [3, 40]. Another mechanism through which yaks may affect soil $\mathrm{N}$ transformations was through altering soil microclimate, such as soil temperature or soil water content [44]. The higher soil $\mathrm{N}$ mineralization and nitrification can be responsible for the higher soil inorganic $\mathrm{N}$ content under heavy grazing intensity $[45,46]$. In comparison, net nitrification did not show a similar pattern as other soil $\mathrm{N}$ transformation rates, the lowest value occurred at the MG site. This might be attributed to the excess consumption of $\mathrm{NO}_{3}{ }^{-} \mathrm{N}$ by the faster accumulating of aboveground biomass at the MG site. Gross nitrification rates were 37-80 times the net nitrification rates, which was similar to the result reported by Sun et al. [47] in a subalpine meadow soil. Higher soil $\mathrm{N}$ transformations under heavy grazing intensity also implied that a potential for leaching losses of $\mathrm{N}$ as $\mathrm{NO}_{3}{ }^{-}$and $\mathrm{N}_{2} \mathrm{O}$ losses, via nitrification or denitrification [48].

\section{Conclusion}

Although heavy grazing intensity resulted in higher levels of plant and soil $\mathrm{N}$, it decreased vegetation coverage and aboveground biomass, which are undesirable for livestock production and sustainable grassland development. What is more, heavy grazing could also introduce potential $\mathrm{N}$ loss via increasing $\mathrm{NO}_{3}{ }^{-}$leaching to ground water and $\mathrm{N}_{2} \mathrm{O}$ emission to the atmosphere. Grazing at light to moderate intensity resulted in the plant communities dominated by forage grasses with high aboveground biomass productivity and $\mathrm{N}$ content. The alpine meadow ecosystems in Tibetan Plateau are very fragile and evolved under grazing by large herbivores; therefore, without an appropriate level of grazing in a long term perspective on an ecological timescale, deterioration of the plant-soil system, and possible declines in soil $\mathrm{N}$, are indicated. 
Acknowledgements. This study was financially supported by the Key project of the National " $10^{\text {th }}$ Fiveyear Plan" of China (2001BA606A-05), the National Natural Science Foundation of China (90511003), the Important Orientation Project of the Chinese Academy of Sciences (KSCXI-07, KSCX2-01-09), the Project of "100 Distinguished Yong Scientists" of the Chinese Academy of Sciences (2004) and the Youth Sci \& Tech Foundation of Sichuan (03ZQ026-043), China. The authors thank Prof. T. Wei for his help on identification of plant species, and Mr. J. Chen and Mrs. J. Pei for their help in the laboratory work.

\section{REFERENCES}

[1] Williams, R.E., Alfred, B.W., DeNio, R.M., Paulsen, H.E. (1968): Conservation, development, and use of the world's rangelands. - J. Range Manage. 21(6): 355-360.

[2] Gitay, H., Brown, S., Easterling, W., Jallow, B. (2001): Ecosystems and their goods and services. - In Contribution of Working Group II to the Third Assessment Report of the Intergovernmental Panel on Climate Change. Cambridge University Press, Cambridge; pp, 197-84.

[3] McNaughton, S.J., Reuss, R.W., Seagle, S.W. (1988): Large mammals and process dynamics in African ecosystems. - BioScience 38: 794-800.

[4] Vitousek, P.M. (1982): Nutrient cycling and nutrient use efficiency. - Am. Nat. 119: 553572.

[5] McNaughton, S.J. (1985): Ecology of a grazing ecosystem: the Serengeti. - Ecol. Monogr. 55: 259-295.

[6] Day, T.A., Detling, J.K. (1990): Grassland patch dynamics and herbivore grazing preference following urine deposition. - Ecology 71: 180-188.

[7] Pastor, J., Dewey, B., Naiman, R.J., McInnes, P.F., Cohen, Y. (1993): Moose browsing and soil fertility in the boreal forests of Isle Royale National Park. - Ecology 74: 467480.

[8] Frank, D.A., Evans, R.D. (1997): Effects of native grazers on grassland N cycling in Yellowstone National Park. - Ecology 78: 2238-2248.

[9] Seastedt, T.R. (1985): Maximization of primary and secondary productivity by grazers. Am. Nat. 126: 559-564.

[10] Holland, E.A., Parton, W.J., Detling, J.K., Coppock, D.L. (1992): Physiological responses of plant populations to herbivory and their consequences for ecosystem nutrient flow. - Am. Nat. 140: 685-706.

[11] Caldwell, M.M., Richards, J.H., Johnson, D.A., Nowak, R.S., Dzurec, R.S. (1981): Coping with herbivory: photosynthetic capacity and resource allocation in two semiarid Agropyron bunchgrasses. - Oecologia 50: 14-24.

[12] Miller, R.F., Rose, J.A. (1992): Growth and carbon allocation of Agropyron desertatum following autumn defoliation. - Oecologia 89: 482-486.

[13] Holland, E.A., Detling, J.K. (1990): Plant response to herbivory and belowground nitrogen cycling. - Ecology 71: 1040-1049.

[14] Green, R.A., Detling, J.K. (2000): Defoliation-induced enhancement of total aboveground nitrogen yield of grasses. - Oikos 91: 280-284.

[15] Olofsson, J., Kitti, H., Rautiainen, P., Stark, P., Oksanen, L. (2001): Effects of summer grazing by reindeer on composition of vegetation, productivity and nitrogen cycling. Ecography 24: 13-24.

[16] Olofsson, J., Oksanen, L. (2002): Role of litter decomposition for the increased primary production in areas heavily grazed by reindeer: a litter bag experiment. - Oikos 96: 507515 . 
[17] Zheng, D., Zhang, Q., Wu, S. (2000): Mountain Geoecology and Sustainable Development of the Tibetan Plateau. Kluwer Academic Publishers, Dordrecht, The Netherlands. 389pp.

[18] Wu, N., Liu, Q. (1999): Ecological environment and strategies for sustainable development on the upper reaches of the Yangtze River. - World Sci-Tech R \& D 21: 7073.

[19] Zhou S.R. (1998): Grassland Resource of Sichuan. Sichuan People Press, Chengdu. pp, 141-153.

[20] Chinese soil taxonomy research group. (1995): Chinese Soil Taxonomy. - Science Press, Beijing. pp, 58-147.

[21] Gan Y.M., Li Z.D., Ze B., Fei D.P., Luo G.R., Wang Q., Wang X.L (1995): The Changes of grassland soil nutrition at different degradation alpine meadow of north-west in Sichuan. - Acta Prataculturae Sinica 14: 38-42.

[22] Eno, C.F. (1960): Nitrate production in the field by incubating the soil in polyethylene bags. - Soil Sci. Soc. Am. Proc. 24: 277-279.

[23] Ingwersen, J., Butterbach-Bahl, K., Gasche, R., Richter, O., Papen, H. (1999): Barometric process separation: new method for quantifying nitrification, denitrification, and nitrous oxide sources in soils. - Soil Sci. Soc. Am. J. 63: 117-128.

[24] Lu, R.K. (2000): Analytic Handbook of Soil Agriculture Chemistry. - Chinese Agricultural Science and Technology Press, Beijing. pp, 146-165.

[25] Wu, N., Liu, J., Yan Z. L. (2004): Grazing intensity on the plant diversity of alpine meadow in the eastern Tibetan Plateau. - Rangifer 15: 9-15.

[26] De Soyza, A.G., Whitford W.G., Herrick J.E., Van Zee, J.W., Havstad K.M. (1998): Early warning indicators of desertification: examples of tests in the Chihuahuan Desert. J. Arid Environ. 39: 101-112.

[27] Pierson E.A., Mack R.N., Black R.A. (1990): The effect of shading on photosynthesis, growth, and regrowth following defoliation for Bromus tectorurn. - Oecologia 84: 534543.

[28] Milchunas, D.G., Lauenroth, W.K. (1993): Quantitative effects of grazing and soils over a global range of environments. - Ecol. Monogr. 63: 327-366.

[29] Turner, C.L., Seastedt, T.R., Dyer, M.I. (1993): Maximization of aboveground grassland production: the role of defoliation frequency, intensity, and history. - Ecol. Appl. 3: 175186.

[30] Frank, D.A., Kuns, M.M., Guido, D.R. (2002): Consumer control of grassland plant production. - Ecology 83: 602-606.

[31] Yang, F.T., Shao, Q., Zhang, S.L. (1982): The primary production of alpine shrub and meadow on the Qinghai Plateau. - In: Xiao, W. P. (ed.) Alpine Meadow Ecosystem. Gansu People Press, Lanzhou. pp, 44-51.

[32] Wang, R.Z., Gao, Q., Chen, Q.S. (2003): Effects of climate change on biomass and biomass allocation in Leymus chinensis (Poaceae) along the Northeast China Transect (NECT). - J. Arid Environ. 54: 653-665.

[33] Coley, P.D., Bryant, J.P., Chapin, III, F.S. (1985): Resource availability and plant antiherbivore defense. - Science 230: 895-899.

[34] Chapin, F.S., Vitousek, III, P.M., Van Cleve, K. (1986): The nature of nutrient limitation in plant communities. - Am. Nat. 127: 48-58.

[35] Jaramillo, V.J., Detling, J.K. (1988): Grazing history, defoliation, and competition: effects on shortgrass production and nitrogen accumulation. - Ecology 69: 1599-1608.

[36] Chaneton, E.J., Lemcoff. J.H., Lavado, R.S. (1996): Nitrogen and phosphorus cycling in grazed and ungrazed plots in a tempetate subhumid grassland in Argentina. - J. Appl. Ecol. 33: 291-302.

[37] Bobbink, R., den Dubbelden, K., Willems, J.H. (1989): Seasonal dynamics of phytomass and nutrients in chalk grassland. - Oikos 55: 216-224. 
[38] Hobbs, N.T., Schimel, D.S., Owensby, C.E., Ojima, D.S. (1991): Fire and grazing in the tallgrass prairie: contingent effects on nitrogen budgets. - Ecology 72: 1374-1382.

[39] Dormaar, J.F., Smoliak, S., Willms, W.D. (1990): Distribution of nitrogen fractions in grazed and ungrazed fescue grassland Ah horizon. - J. Range. Manage. 43(1): 6-9.

[40] Manley, J.T., Schuman, G.E., Reeder, J.D., Hart, R.H. (1995): Rangeland soil carbon and nitrogen responses to grazing. - J. Soil Water Conserv. 50: 294-298.

[41] Schuman, G.E., Reeder, J.D., Manley, J.T., Hart, R.H., Manley, W.A. (1999): Impact of grazing management on the carbon and nitrogen balance of a mixed-grass rangeland. Ecol. Appl. 9: 65-71.

[42] Hibbard, K.A., Archer, S., Schimel, D.S., Valentine, D.W. (2001): Biogeochemical changes accompanying woody plant encroachment in a subtropical savanna. - Ecology 82: 1999-2011.

[43] Le Roux, X., Bardy, M., Loiseau, P., Louault, F. (2003): Stimulation of soil nitrification and denitrification by grazing in grasslands: do changes in plant species composition matter? - Oeocologia 137: 417-425.

[44] Frank, D.A., Groffman, P.M., Evans, R.D., Tracy, B.F. (2000): Ungulate stimulation of nitrogen cycling and retention in Yellowstone Park grasslands. - Oecologia 123:116-121.

[45] Tracy, B.F., Frank, D.A. (1998): Herbivore influence on soil microbial biomass and nitrogen mineralization in a northern grassland ecosystem: Yellowstone National Park. Oecologia 114: 556-562.

[46] Bengtsson, G., Bengtson, P., Mansson, K.F. (2003): Gross nitrogen mineralization-, immobilization-, and nitrification rates as a function of soil $\mathrm{C} / \mathrm{N}$ ratio and microbial activity. - Soil Boil. Biochem. 35(1): 143-154.

[47] Sun, G., Wu, N., Luo, P. (2005): Soil N pools and Transformation rates under different land uses in a subalpine forest-grassland ecotone. - Pedosphere 15(1): 52-58.

[48] Fierer, N., Schimel, J.P. (2002): Effects of drying-rewetting frequency on soil carbon and nitrogen transformations. - Soil Biol. Biochem. 34(6): 777-787. 